\title{
A review of seventeen years of bank filtration in Brazil: results, benefits and challenges - Part 1: state of Santa Catarina
}

\section{Revisão de dezessete anos de estudos em filtração em margem no Brasil: resultados, benefícios e desafios - Parte 1: Estado de Santa Catarina}

Data de entrada: 04/04/2019

Data de aprovação: $26 / 05 / 2020$

\author{
ORCID ID \\ Emmendoerfer ML (D) https://orcid.org/0000-0003-1346-6267 \\ Martins M (DD https://orcid.org/0000-0003-4623-2993 \\ Pizzolatti BS (D) https://orcid.org/0000-0002-2765-7040
}

Marcelo Luiz Emmendoerfer ${ }^{1 *}$ | Marcelle Martins ${ }^{2}$ | Bruno Segalla Pizzolatti ${ }^{1}$ Marcus Bruno Domingues Soares ${ }^{2}$ | Aline Maria Signori' | Maurício Luiz Sens ${ }^{1}$
DOI: https://doi.org/10.36659/dae.2021.082
Soares MBD (D) https://orcid.org/0000-0002-0857-707X

Signori AM (D) https://orcid.org/0000-0003-1416-6258 Sens ML (D) https://orcid.org/0000-0001-5013-4267

\section{Abstract}

This work is the first part of a national review about Bank Filtration (BF) that began in 2003, in Brazil. These studies were conducted in the laboratory and in the field with water and natural sediment from the study regions, showing how BF has been efficient worldwide for the treatment of water for public supply as an alternative treatment. It aims to show the synthesis of results to date and point out its main benefits and challenges; that is, the state of the art at the national level. The review is concentrated in Santa Catarina (part 1), Pernambuco and Minas Gerais (part 2). BF demonstrates efficiency in reducing parameters such as turbidity and coliforms (total and fecal), pesticides and toxins. However, BF showed low capacity in reducing parameters such as salinity and true color. BF is highly dependent on local geological conditions, so parameters such as iron, manganese, fluorine, alkalinity, hardness, and chlorides can be added to the treated water.

Keywords: Water Treatment. Bank Filtration. Public Supply Systems. Natural Sediment. Water Quality.

\section{Resumo}

Este trabalho é a primeira parte de uma revisão nacional sobre Filtragem em Margem (FM), iniciada em 2003 no Brasil. Os estudos foram realizados em laboratório e em campo com água e sedimentos naturais das regiões estudadas, mostrando como a FM tem sido eficiente mundialmente no tratamento alternativo de água para abastecimento público. Tem como objetivo mostrar a síntese dos resultados até o momento e apontar os principais benefícios e desafios; isto é, o estado da arte em nível nacional. A revisão está concentrada nos Estados de Santa Catarina (parte 1), Pernambuco e Minas Gerais (parte 2). A FM demonstra eficiência na redução de parâmetros como: turbidez e coliformes (total e fecal), pesticidas e toxinas. Entretanto, a FM apresentou baixa capacidade de reduzir parâmetros como: salinidade e cor verdadeira. A FM é dependente das condições geológicas locais assim, parâmetros como ferro, manganês, flúor, alcalinidade, dureza e cloretos podem ser adicionados à água tratada.

Palavras-chave: Tratamento de água; Filtração em Margem, Sistemas de Abastecimento Público; Sedimento Natural; Qualidade de Água.

\footnotetext{
${ }^{1}$ Universidade Federal de Santa Catarina - Florianópolis - Santa Catarina - Brasil.

${ }^{2}$ Universidade Federal de Santa Maria - Campus Frederico Westphalen - Rio Grande do Sul - Brasil.

* Autor correspondente: marcelo.ensagmail.com.
} 


\section{INTRODUCTION}

The increasing industrialization of Brazil in recent years has brought incalculable damage to the environment, especially to surface waters, where deterioration has brought technical challenges to water treatment technologies already employed. Thus, water pretreatment technologies have been widely studied to ensure that treatment plants meet national potability standards.

Bank Filtration (BF) is a water treatment technology that has been used for over 140 years throu- ghout Europe (RAY et al., 2003; SOARES, 2015). In Brazil, this technology has been studied for 17 years, limited to small-scale field studies, with no reports on this technology implementation in full scale. BF consists of the use of natural materials from the bank itself and from the bottom of the source as a filtering medium. It occurs through the positive, natural or induced hydraulic gradient (through pumping) in wells with hydraulic connection, built near the banks of the surface well (Fig. 1).

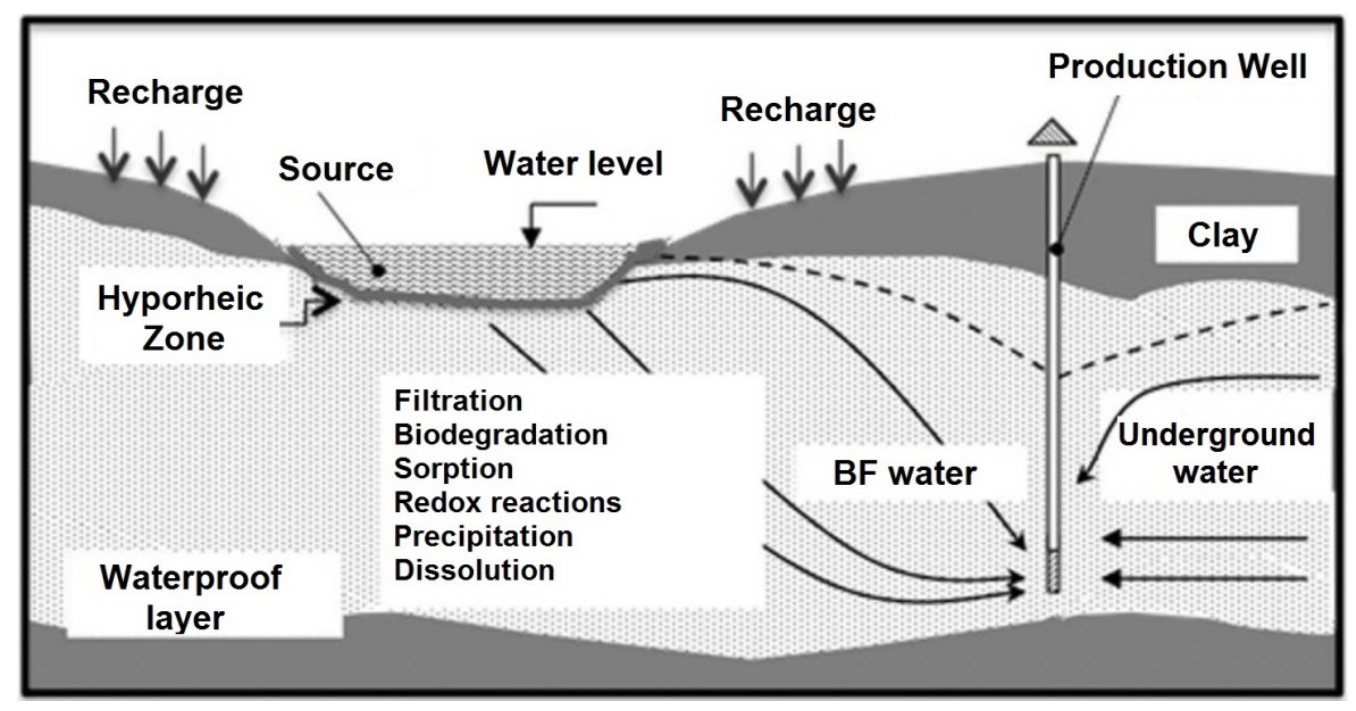

Figure 1 - Operation diagram of Bank Filtration

Source: Esquivel et al. (2012), adapted from Hiscock and Grischek (2002) and Sens et al. (2006)

This gradient induces the water flow through the soil, which removes or attenuates the contaminants present in the surface water in the source-production well route. Captured water is a mixture of both aquifer and surface water percolated by the bank. The proportion of filtered well water captured from wells depends on a number of factors, including bottom depth and permeability, water viscosity, stock elevation, and pumping rates.

According to Donald and Grygaski (2002) apud Sens et al. (2006), the BF system location requi- res important information about local soil characteristics, such as:

1. Hydraulic conductivity: it is recommended that the value is at least 1 to $2 \mathrm{~m} / \mathrm{d}$.

2. Porosity: the larger the grain size and its porosity value, the greater the specific porosity or specific flow of the aquifer.

3. Particle size analysis: the larger the grain size, the larger the pore size.

4. Organic matter content: the presence of soil layers or pockets with OM can give water 
undesirable characteristics, such as color, taste, and odor.

In addition to physical retention, several other phenomena occur during the water flow towards the well, since the bank soil contains microorganisms that can act in certain substances (pesticides, toxins, organic matter, among others), promoting water quality improvement. Thus, BF works as a low-cost pretreatment in the production of high-quality water supply and can perform as the only treatment before disinfection (MONDARDO, 2009).

BF has been applied in Europe to produce water for supply, most often along the Rhine, Elbe and Danube rivers (RAY et al., 2003). In the United States, interest has grown because it is a low-cost, complete or alternative treatment for filtration systems to remove waterborne pathogens, such as Giardia, Cryptosporidium and viruses (SENS et al., 2006).

The first known BF use for water supply purposes was from a company in the United Kingdom (Glasgow Waterworks), which built a drainage pipe parallel to the Clyde River in 1810 to extract filtered water from the riverbank. In the mid-nineteenth century, BF was officially adopted in Europe to produce drinking water. In Western Europe, one of the first BF facilities was built in Germany on both sides of the Rhine River due to limited groundwater resources in the region. Due to an outbreak of the cholera epidemic in Hamburg, Germany, in 1892, caused by the direct use of the waters of the Elbe River for public supply, the use of artificial or natural passages of underground river water as a new form of water abstraction for human consumption has become essential. Statistical data from 1998 showed that, among sources used for water supply by members of the Rhine River Sanitation Association (German and Dutch side), $49 \%$ corresponded to BF and groundwater recharge (RAY et al., 2003).
Some BF facilities on the Danube have been operating for over a century, near the cities of Vienna, Austria, and Bratislava in the Slovak Republic. Other important BF projects can be found in Budapest, and in the city of Belgrade in Yugoslavia (SENS et al., 2006). In Brazil, BF has been used for some time, without being named, in the Upper Itajaí Valley - Santa Catarina State, through wells of 1.2 to $1.5 \mathrm{~m}$ in diameter, built along the rivers of Itajaí do Sul, Itajaí do Oeste and Itajaí do Norte (tributaries of the Itajaí Açu River) (SENS et al., 2006).

This work is a national review in the field of bank filtration technology that shows the results obtained over 17 years of studying BF in Brazil to date and point out the main benefits and challenges of the technique; that is, the state of the art at the national level. It was divided into two parts for a better understanding and organization of the content on bank filtration: Part 1 describes the researches performed in the state of Santa Catarina, and Part 2 describes the researches performed in the states of Pernambuco and Minas Gerais. This first part was compiled on a result matrix, from which tables were created containing physical, chemical, biological and specific contaminant parameters. For each grouping of results, there was a discussion of the elaborated table.

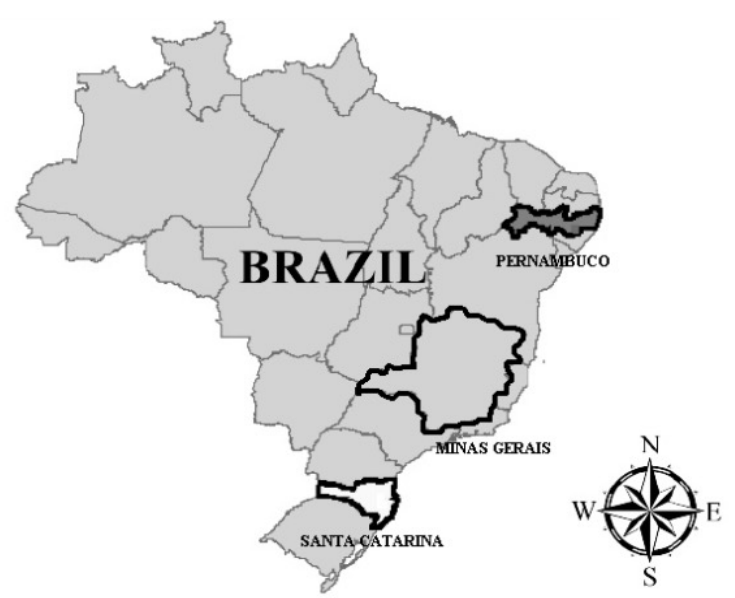

Figure 2 - Map of Brazil indicating the three federative states involved in BF research: Santa Catarina, Minas Gerais and Pernambuco states Source: Authors 
A bibliographic search was performed in national and international databases, including articles, theses, dissertations, book chapters and course conclusions, totaling 53 documents that indicated that research on the subject is concentrated in the States of Santa Catarina, Pernambuco and Minas Gerais (Fig. 2).

\section{STUDIES CARRIED OUT IN THE STATE OF SANTA CATARINA}

The first studies in Brazil using the BF technique were performed in 2003 in Peri Lake, located in the south of Florianópolis island, in the state of Santa Catarina (SC), located in southern Brazil (SENS et al., 2006). Another study location in the city of Florianópolis took place in the Barra da Lagoa region (BURGARDT, 2017). The state of Santa Catarina had two other study sites as well: the city of Ituporanga, in an aquaculture lake (SOARES, 2009) and the Itajaí do Sul river (MICHELAN, 2010), and the city of Orleans, in the Belo River (GUEDES, 2018). The study sites in the state of Santa Catarina are shown in Fig. 3.

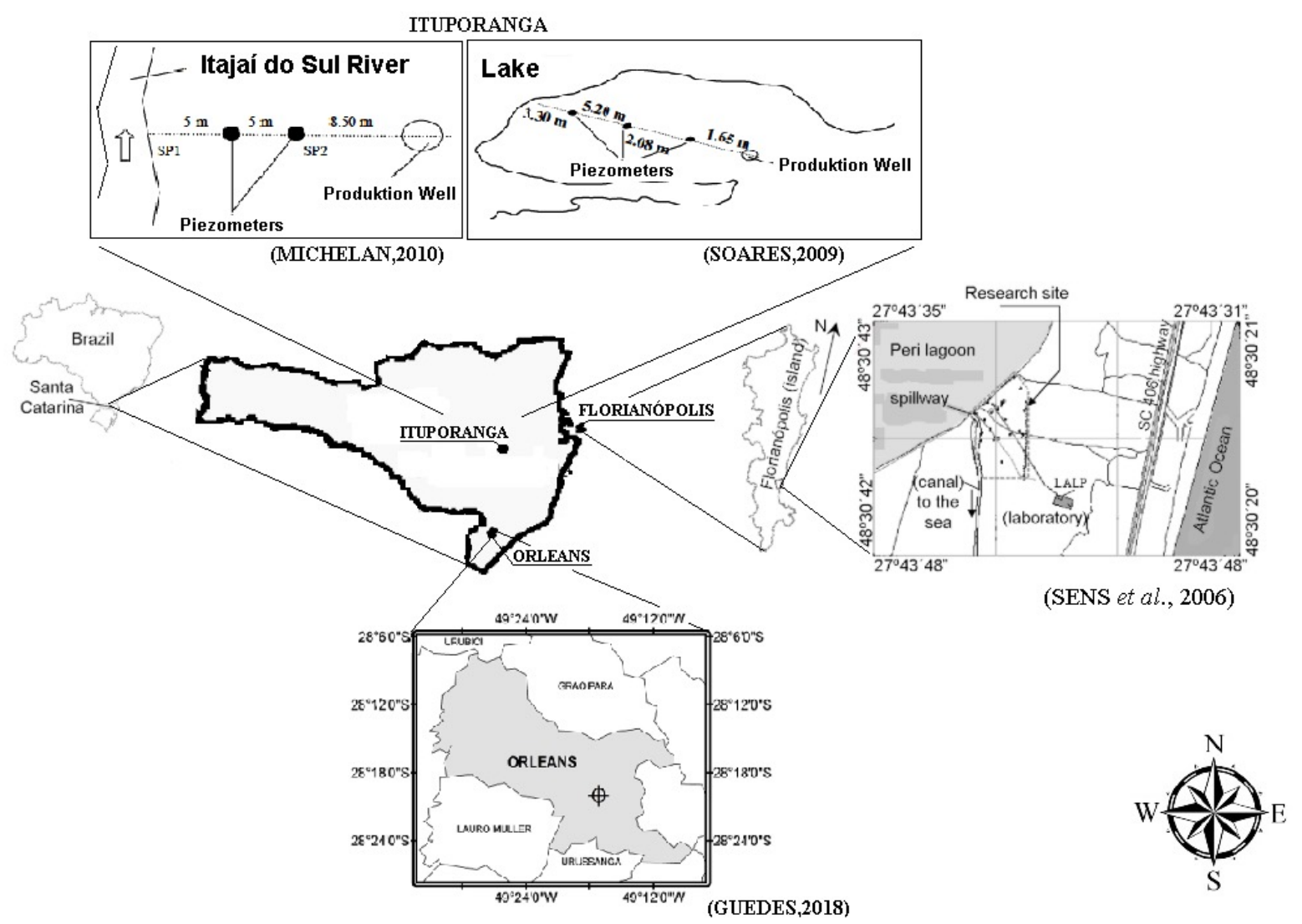

Figure 3 - Location of the study points of the BF technique - Santa Catarina, Brazil Source: Adapted by the authors from Sens et al. (2006), Soares (2009), Michelan (2010) and Guedes (2018)

\subsection{Peri Lake - Florianópolis (SC): Lake bank characterization}

Peri Lake is located in the southern region of Florianópolis island. The lake has approximately 5.0 $\mathrm{km}^{2}$ (SILVA, 1999), an average depth of $4.2 \mathrm{~m}$, its deepest part reaches $11 \mathrm{~m}$ (SIMONASSI, 2001). The aquifer has an average depth of $20 \mathrm{~m}$, a hydraulic conductivity of $1 \times 10^{-4} \mathrm{~m} / \mathrm{s}$ and an effective porosity of $25 \%$ (ESQUIVEL et al., 2012). The lake water is approximately $3 \mathrm{~m}$ above sea level 
with no saline wedge intrusion (CAMPOS, 2012). The studies were conducted in an area with marine deposits (SANTOS et al., 1989; OLIVEIRA, 2002). The design of the production well (P1) began in 2003 at $20 \mathrm{~m}$ from the shore of the lagoon (SENS et al., 2006). In 2011, this well was replaced by a new one with a smaller diameter (P2), keeping the same distance from the lake (ESQUIVEL et al., 2017).

The sediment analysis carried out from the bottom of the lake, near the wells, showed the presence of $85 \%$ of fine sand in the bottom of the Peri Lake (in the first $50 \mathrm{~cm}$ ), and 13\% medium/ coarse sand, with little depth variation, and detection of 4\% clay (MONDARDO, 2009; ESQUIVEL et al., 2012; SOARES, 2015; SOARES et al., 2019). The presence of organic matter (OM) was also found in the order of $27 \%$ in the first $30 \mathrm{~cm}$ depth (SENS and DALSASSO, 2007).

The effective diameter values (d10) in Peri Lake were similar in the first $50 \mathrm{~cm}$, indicating hydraulic conductivity from $1.7 \times 10^{-4}$ to $2.9 \times 10^{-4}$ m/s (RABELO, 2006; ESQQUIVEL et al., 2012; SOARES, 2015; SOARES et al., 2019). The sediment site also has a low curvature coefficient (mean CC of 1.0) and a low uniformity coefficient (mean CU 1.4), indicating uniformity of grains and sediments with grain size tending to homogeneity (ESQUIVEL et al., 2012; SOARES, 2015; SOARES et al., 2019). The low specific porosity, ranging from $25 \%$ to $26 \%$, is attributed to the organic deposition of compounds and/or presence of retained gases in the medium (physical and biological clogging) (ESQUIVEL et al., 2012).

Through soil evaluation to a large extent, marine sediments were identified in its composition, with dark sand (since there is OM) up to about 1 $m$ deep, fine sand (also containing OM) from 1 to $4 \mathrm{~m}$ deep, fine white sand between 4 and $18 \mathrm{~m}$, and clay between 18 and $23 \mathrm{~m}$. The presence of fine sand falls on a scale of 80 to $99 \%$ in the first
$5.5 \mathrm{~m}$ depth (SENS et al., 2006; SENS and DALSASSO, 2007; ESQUIVEL et al., 2016).

Sens et al. (2007) built P1 with $100 \mathrm{~mm}$ in diameter, $12 \mathrm{~m}$ deep and the filter in the last $4 \mathrm{~m}$, approximately $20 \mathrm{~m}$ from the lake. Monitoring studies have indicated that the flow naturally proceeded towards the main well (SENS and DALSASSO, 2007; MONDARDO, 2009). Two protection wells were also built on each side of P1 to ensure that the water infiltrated preferably came from Peri Lake (SENS et al., 2006). When P2 was built, with $50 \mathrm{~mm}$ in diameter and $12 \mathrm{~m}$ deep, $20 \mathrm{~m}$ from Peri Lake and a $2 \mathrm{~m}$ filter, $\mathrm{P} 1$ was decommissioned (ESQUIVEL et al., 2017). Seven piezometers were drilled, four of them $12 \mathrm{~m}$ deep, located at 8, 40, 55 and $57 \mathrm{~m}$ from the bank, and the remaining at 4 , 5, and $6 \mathrm{~m}$ deep, $1 \mathrm{~m}$ from the bank (ESQUIVEL et al., 2012, 2016, 2017). The quality of bank filtered water in P1 and P2 are discussed in Table 1. The saturated aquifer layer (D) was defined as roughly $18 \mathrm{~m}$, with effective porosity (ne) corresponding to $20 \%$ (SENS et al., 2006; SENS and DALSASSO, 2007; ESQUIVEL et al., 2012). The pumping flow (Q) in the first study corresponded to $24 \mathrm{~m}^{3} / \mathrm{d}$ (approximately $0.26 \mathrm{~L} / \mathrm{s}$ ), obtaining hydraulic conductivity (K) of $1.49 \times 10^{-5} \mathrm{~m} / \mathrm{s}$, and $1.5 \times 10^{-4} \mathrm{~m} / \mathrm{s}$, and the vertical conductivity (Kv) obtained was $1.42 \times 10^{-5} \mathrm{~m} / \mathrm{s}$ and horizontal (Kv), $1.42 \times 10^{-4} \mathrm{~m} / \mathrm{s}$ (SENS et al., 2006; SENS and DALSASSO, 2007; ESQUIVEL et al., 2012). After $48 \mathrm{~h}$ of pumping, the well lowered about $0.6 \mathrm{~m}$ (SENS et al., 2006; SENS and DALSASSO, 2007). The water's travel time from the lake to the well was about 10 days for the $5.5 \mathrm{~m}$ deep well, and 14 days for $\mathrm{P} 1$ with a depth of $12 \mathrm{~m}$ (SENS and DALSASSO, 2007).

\subsubsection{Water quality characterization: physical, chemical and biological parameters}

Table 1 shows raw water physical parameters (RW - water from the source - Peri Lake) and filtered water (FW - water in production wells - P1 or P2) 
between the years 2004 and 2017 (SENS et al., 2006; SENS and DALSASSO, 2007; MONDARDO, 2009; CAMPOS, 2012; ESQUUIVEL et al., 2012, 2016, and 2017).

As observed, BF was very effective in turbidity removal, in both P1 and P2, (94 and 97\% average removal, respectively) and consequently, apparent color (89 and 93\% removal, respectively). Not as expressively, advantageous BF results in true color removal were noted as well. In pro- duction well P1 (SENS et al., 2006; MONDARDO, 2009), the total dissolved solids (TDS) increased at an average of 3.2 times. The authors pointed out that the increase in TDS was due to the presence of calcium sediment at the site, which was also related to the increase in P1 conductivity ( 3 times), total hardness (7 times) and total alkalinity (11 times) as per Table 2. Moreover, it was considered that TDS variation was caused by the leaching of existing compounds in the soil.

Table 1 - Results of the physical parameters obtained in Peri Lake.

\begin{tabular}{|c|c|c|c|c|c|}
\hline & $\begin{array}{l}\text { Apparent color } \\
\text { (Pt-Co Units) }\end{array}$ & $\begin{array}{l}\text { True color } \\
\text { (Pt-Co Units) }\end{array}$ & Turbidity (NTU) & TDS (mg/L) & Temperature ${ }^{\circ} \mathrm{C}$ \\
\hline Ref. & $\begin{array}{l}\text { (ESQUIVEL et al., 2017; } \\
\text { MONDARDO, 2009; } \\
\text { SENS and DALSASSO, } \\
\text { 2007; SENS et al., 2006) }\end{array}$ & $\begin{array}{l}\text { ESQUIVEL et al., 2017; } \\
\text { MONDARDO, 2009; } \\
\text { SENS and DALSASSO, } \\
\text { 2007; SENS et al., 2006) }\end{array}$ & $\begin{array}{l}\text { ESQUIVEL et al., 2017; } \\
\text { MONDARDO, 2009; } \\
\text { SENS and DALSASSO, } \\
\text { 2007; SENS et al., 2006) }\end{array}$ & $\begin{array}{l}\text { (MONDARDO, 2009; } \\
\text { SENS et al., 2006) }\end{array}$ & $\begin{array}{l}\text { ESQUIVEL et al., 2017; } \\
\text { MONDARDO, 2009; } \\
\text { SENS and DALSASSO, } \\
\text { 2007; SENS et al., 2006) }\end{array}$ \\
\hline RW & 56 to 78 & 5 to 9.5 & 5.64 to 7.24 & 36 to 36.4 & 20.5 to 25.5 \\
\hline FW (P1) & 2 to 10 & 2 to 5 & $0.22 \mathrm{a} 0.4$ & 111 to 121.6 & 21.4 a 24.4 \\
\hline$\%$ average removal & 89 & 47 & 94 & $x$ & $\mathbf{x}$ \\
\hline \multirow[t]{2}{*}{ FW/RW removal } & $x$ & $x$ & $x$ & 3.2 & $x$ \\
\hline & $\begin{array}{l}\text { Apparent color } \\
\text { (Pt-Co Units) }\end{array}$ & $\begin{array}{l}\text { True color } \\
\text { (Pt-Co Units) }\end{array}$ & Turbidity (NTU) & TDS (mg/L) & Temperature ${ }^{\circ} \mathrm{C}$ \\
\hline Ref. & $\begin{array}{l}\text { (CAMPOS, 2012; } \\
\text { ESOUIVEL et al., 2012, } \\
\text { 2016, and 2017) }\end{array}$ & $x$ & $\begin{array}{l}\text { (CAMPOS, 2012; } \\
\text { ESOUIVEL et al., 2012, } \\
\text { 2016, and 2017) }\end{array}$ & $x$ & $\begin{array}{l}\text { (CAMPOS, 2012; } \\
\text { ESQUIVEL et al., 2012, } \\
\text { 2016, and 2017) }\end{array}$ \\
\hline RW & 61 to 90 & NA & 6.7 & NA & 20.7 \\
\hline FW (P2) & 6 to 6.5 & NA & 0.19 & NA & 22.3 to 22.35 \\
\hline$\%$ average removal & 93 & $\mathbf{x}$ & 97 & $\mathbf{x}$ & $\mathbf{x}$ \\
\hline
\end{tabular}

RW- raw water (source-Peri Lake); FW- filtered water (production well); FW/RW average - average increment of parameter in FW; NA- Not analyzed; NTU- Turbidity Unit; TDS- Total Dissolved Solids.

Source: Adapted by the authors from Sens (2006), Sens and Dalsasso (2007), Mondardo (2009), Campos (2012) and Esquivel (2012, 2016, and 2017)

The RW chemical analysis allowed identification and quantification of polysaccharides (18.8\%), humic substances (39.5\%), block-built humic substances (15.5\%), low molecular weight acids (8.4\%) and $12 \%$ neutral substances (ESQUIVEL et al., 2017). Regarding the water's chemical quality for the BF system (SENS et al., 2006; SENS and DALSASSO, 2007; MONDARDO, 2009; CAMPOS, 2012; ESQQUIVEL et al., 2012, 2016, and 2017), there was a significant increase in alkalinity in P1 and P2, with respect to the supply (10 and 14 times, respectively) and total hardness ( 7 and 9 times, in P1 and P2, respectively) as observed in Table 2.
There was also a 3- to 4-fold increase in electrical conductivity in both wells. Esquivel et al. (2017) mentioned that the increase of these parameters after $\mathrm{BF}$ is justified by the interaction with the aquifer, which has leached minerals in its composition. However, even with the increase of these parameters, as well as total hardness, $\mathrm{Ca}$ hardness and $\mathrm{Mg}$ hardness in FW, they were within the potability standards effective in 2012 (Ministry of Health Ordinance 2914, current Annex XX of Consolidation Ordinance $N^{\circ} 5$ ).

In P2, the hardness results in calcium and magnesium showed an increase of 11 and 2 times, respec- 
tively. In this well, there was also a small increase of manganese and little variation of iron in relation to the source. In terms of the source, the chloride variation in both wells was not significant either. Similar concentrations of chloride in RW and wells P1 and P2 indicated that most of the filtered water comes from the lake (ESQUIVEL et al., 2017). The $\mathrm{pH}$ of the source varied slightly over the 13 years of the study, not exceeding $0.6 \mathrm{pH}$ units. Table 2 shows a small increase in $\mathrm{pH}$ in both wells in relation to the source, which agrees with the observed increase in alkalinity and total hardness.

Table 2 - Results of chemical parameters obtained in Peri Lake.

\begin{tabular}{|c|c|c|c|c|c|c|c|c|c|}
\hline & $\begin{array}{c}\text { Total } \\
\text { Alkalinity } \\
\text { (mg } \\
\left.\mathrm{CaCO}_{3} / \mathrm{L}\right)\end{array}$ & $\begin{array}{l}\text { Chlorides } \\
\text { (mg Cl-/L) }\end{array}$ & $\begin{array}{c}\text { Electrical } \\
\text { conductivity } \\
(\mu \mathrm{S} / \mathrm{cm})\end{array}$ & $\begin{array}{l}\text { Hardness Ca } \\
(\mathrm{mg} / \mathrm{L})\end{array}$ & $\begin{array}{l}\text { Hardness } \\
\mathrm{Mg}(\mathrm{mg} / \mathrm{L})\end{array}$ & $\begin{array}{c}\text { Total } \\
\text { Hardness } \\
\text { (mg } \\
\left.\mathrm{CaCO}_{3} / \mathrm{L}\right)\end{array}$ & $\mathrm{Fe}^{2+}(\mathrm{mg} / \mathrm{L})$ & $\mathrm{Mn}^{2+}(\mathrm{mg} / \mathrm{L})$ & $\mathrm{pH}$ \\
\hline Ref. & $\begin{array}{c}\text { MONDARDO, } \\
2009 ; \\
\text { SENS and } \\
\text { DALSASSO, } \\
\text { 2007; SENS } \\
\text { et al., 2006) }\end{array}$ & $\begin{array}{c}\text { (ESQUIVEL } \\
\text { et al., 2017; } \\
\text { MONDARDO, } \\
2009 ; \\
\text { SENS and } \\
\text { DALSASSO, } \\
\text { 2007; SENS } \\
\text { et al., 2006) }\end{array}$ & $\begin{array}{c}\text { MONDARDO, } \\
2009 ; \\
\text { SENS and } \\
\text { DALSASSO, } \\
\text { 2007; SENS } \\
\text { et al., 2006) }\end{array}$ & $x$ & $x$ & $\begin{array}{c}\text { MONDARDO, } \\
2009 ; \\
\text { SENS and } \\
\text { DALSASSO, } \\
\text { 2007; SENS } \\
\text { et al., 2006) }\end{array}$ & $x$ & $x$ & $\begin{array}{c}\text { MONDARDO, } \\
2009 ; \\
\text { SENS and } \\
\text { DALSASSO, } \\
2007 ; \text { SENS } \\
\text { et al., 2006) }\end{array}$ \\
\hline RW & 7.64 to 9.6 & $\begin{array}{c}17.0 \\
\text { to } 18.15\end{array}$ & 67.08 to 78 & NA & NA & 10.5 a 11.45 & NA & NA & 7.1 to 7.3 \\
\hline FW (P1) & 84.9 to 90 & 17.68 to 19 & 222 to 226 & NA & NA & 74.3 to 85 & NA & NA & 7.6 to 7.88 \\
\hline \multirow[t]{2}{*}{$\begin{array}{l}\text { FW/RW } \\
\text { average }\end{array}$} & 11 & $\mathbf{x}$ & 3 & $x$ & $\mathbf{x}$ & 7 & $x$ & $x$ & $\mathbf{x}$ \\
\hline & $\begin{array}{c}\text { Total } \\
\text { Alkalinity } \\
\text { (mg } \\
\left.\mathrm{CaCO}_{3} / \mathrm{L}\right)\end{array}$ & $\begin{array}{l}\text { Chlorides } \\
\text { (mg Cl} / / L)\end{array}$ & $\begin{array}{c}\text { Electrical } \\
\text { conductivity } \\
(\mu \mathrm{S} / \mathrm{cm})\end{array}$ & $\begin{array}{l}\text { Hardness Ca } \\
\text { (mg/L) }\end{array}$ & $\begin{array}{l}\text { Hardness } \\
\mathrm{Mg}(\mathrm{mg} / \mathrm{L})\end{array}$ & $\begin{array}{c}\text { Total } \\
\text { Hardness } \\
\text { (mg } \\
\left.\mathrm{CaCO}_{3} / \mathrm{L}\right)\end{array}$ & $\mathrm{Fe}^{2+}(\mathrm{mg} / \mathrm{L})$ & $\mathrm{Mn}^{2+}(\mathrm{mg} / \mathrm{L})$ & $\mathrm{pH}$ \\
\hline Ref. & $\begin{array}{c}\text { (CAMPOS, } \\
2012 ; \\
\text { ESQUIVEL } \\
\text { et al., 2012, } \\
2016, \text { and } \\
2017)\end{array}$ & $\begin{array}{c}\text { (CAMPOS, } \\
2012 ; \\
\text { ESQUIVEL } \\
\text { et al., 2012, } \\
2016 \text {, and } \\
2017)\end{array}$ & $\begin{array}{c}\text { (CAMPOS, } \\
2012 ; \\
\text { ESQUIVEL } \\
\text { et al., 2012, } \\
2016, \text { and } \\
2017)\end{array}$ & $\begin{array}{c}\text { (CAMPOS, } \\
2012 ; \\
\text { ESQUIVEL } \\
\text { et al., 2012, } \\
\text { 2016, and } \\
2017)\end{array}$ & $\begin{array}{c}\text { (CAMPOS, } \\
2012 ; \\
\text { ESQUIVEL } \\
\text { et al., 2012, } \\
2016, \text { and } \\
2017)\end{array}$ & $\begin{array}{c}\text { (CAMPOS, } \\
2012 ; \\
\text { ESQUIVEL } \\
\text { et al., 2012, } \\
2016, \text { and } \\
2017)\end{array}$ & $\begin{array}{c}\text { (CAMPOS, } \\
2012 ; \\
\text { ESQUIVEL } \\
\text { et al., 2012, } \\
2016, \text { and } \\
2017)\end{array}$ & $\begin{array}{c}\text { (CAMPOS, } \\
2012 ; \\
\text { ESQUIVEL } \\
\text { et al., 2012, } \\
2016 \text {, and } \\
2017)\end{array}$ & $\begin{array}{c}\text { (CAMPOS, } \\
2012 ; \\
\text { ESQUIVEL } \\
\text { et al., 2012, } \\
2016, \text { and } \\
2017)\end{array}$ \\
\hline RW & 7.4 to 8 & 11.9 to 12 & 64 to 74 & 7.8 to 7.86 & 4.2 & 10.2 to 11.53 & $\begin{array}{c}0.013 \text { to }< \\
0.03\end{array}$ & $\begin{array}{c}\text { to }<0.007 \text { to } \\
0.02\end{array}$ & 6.83 to 7.38 \\
\hline $\mathrm{FW}(\mathrm{P} 2)$ & 105.5 & 14 to 14.7 & 235 & 85 to 85.6 & 10 to 10.5 & 95.8 to 96 & 0.01 & 0.094 & 7.86 \\
\hline $\begin{array}{l}\text { FW/RW } \\
\text { average }\end{array}$ & 14 & $x$ & 4 & 11 & 2 & 9 & $x$ & $\mathbf{x}$ & $\mathbf{x}$ \\
\hline
\end{tabular}

RW- raw water (source-Peri Lake); FW- filtered water (production well); FW / RW average - average increment of parameter in FW; NA- Not analyzed Source: Adapted by the authors from Sens (2006), Sens and Dalsasso (2007), Mondardo (2009), Campos (2012), Esquivel (2012, 2016, and 2017)

In isolation, Esquivel et al. (2017) also analyzed bromides in RW and FW in well P2, not observing variations. Furthermore, 3.1 and $34 \mathrm{mg} / \mathrm{L}$ of calcium and 1 and $2.4 \mathrm{mg} / \mathrm{L}$ of magnesium were obtained in RW and FW, respectively. The increase in the values of these parameters aligns with the increase of total hardness.

Changes were observed in alkalinity, total hardness and conductivity conditions in FW, as evidenced by studies performed in P1 (Table 2), as well as complementary chemical aspects of FW (Table 3). These changes were justified by Sens et al. (2006), who attributed them to the presence of calcium sediments in the geological profile, observing fragments during well drilling. Nevertheless, the authors considered that there was a great influence of sediments on the increase of the electrical conductivity from the lake. The same chemical behavior aforementioned was observed in $\mathrm{P} 2$.

Regarding the evaluation of nitrate ions, Mondardo (2009) observed the appearance of 1.24 $\mathrm{mg} / \mathrm{L}$ in $\mathrm{P} 1$. The other authors did not detect variations between the source and the produc- 
tion well (SENS et al., 2006; SENS and DALSASSO, 2007; ESQQUIVEL et al., 2012, 2016, and 2017) except Sens et al.(2006), who noted a small 1.25fold increase in nitrate ions in FW $(1.93 \mathrm{mg} / \mathrm{L})$, the appearance of ammoniacal nitrogen (between 1.2 and $1.9 \mathrm{mg} \mathrm{NH}_{3}{ }^{-} \mathrm{N} / \mathrm{L}$ ) (SENS et al., 2006; SENS and DALSASSO, 2007), and the removal of $100 \%$ of chlorophyll in well P1 (SENS and DALSASSO, 2007). There was no evaluation of these parameters in P2. Some authors (CAMPOS, 2012;
ESQUIVEL et al., 2016) observed a 2-fold increase in the concentration of hydrogen sulfide in $\mathrm{P} 2$ as well (Table 4).

Table 3 shows the absorbance $254 \mathrm{~nm}$ results, which indicates a considerable removal of dissolved organic matter (DOM) in P1 (66\%) and 29\% in P2. In addition, there was a significant decrease in total organic carbon (TOC) and dissolved oxygen (DO) in P1 and 98\% of DO decrease in P2.

Table 3 - Results of complementary chemical parameters.

\begin{tabular}{|c|c|c|c|c|c|}
\hline & $\begin{array}{l}\text { Absorbance } 254 \mathrm{~nm} \\
\qquad\left(\mathrm{~cm}^{-1}\right)\end{array}$ & $\mathrm{DOC}(\mathrm{mg} / \mathrm{L})$ & TOC (mg/L) & $\mathrm{DO}\left(\mathrm{mg} \mathrm{O}_{2} / \mathrm{L}\right)$ & $\begin{array}{l}\text { Orthophosphate (mg } \\
\left.\qquad \mathrm{PO}_{4}^{-3} / \mathrm{L}\right)\end{array}$ \\
\hline Ref. & $\begin{array}{l}\text { MONDARDO, 2009; } \\
\text { SENS and DALSASSO, } \\
\text { 2007) }\end{array}$ & $x$ & $\begin{array}{l}\text { (MONDARDO, 2009; } \\
\text { SENS and DALSASSO, } \\
\text { 2007) }\end{array}$ & $\begin{array}{l}\text { (MONDARDO, 2009; } \\
\text { SENS and DALSASSO, } \\
\text { 2007; SENS et al., 2006) }\end{array}$ & $\begin{array}{l}\text { MONDARDO, 2009; } \\
\text { SENS and DALSASSO, } \\
\text { 2007; SENS et al., 2006) }\end{array}$ \\
\hline RW & 0.116 to 0.14 & NA & 7.1 to 7.27 & 6.82 to 7.36 & 0.05 to 0.66 \\
\hline FW (P1) & 0.019 to 0.067 & NA & 1.8 to 1.93 & 2.48 to 2.64 & 0.46 to 0.49 \\
\hline \multirow[t]{2}{*}{$\%$ average removal } & 66 & $\mathbf{x}$ & 74 & 64 & 2 \\
\hline & $\begin{array}{c}\text { Absorbance } 254 \mathrm{~nm} \\
\left(\mathrm{~cm}^{-1}\right)\end{array}$ & DOC (mg/L) & TOC (mg/L) & $\mathrm{DO}\left(\mathrm{mg} \mathrm{O}_{2} / \mathrm{L}\right)$ & $\begin{array}{c}\text { Orthophosphate (mg } \\
\left.\mathrm{PO}_{4}^{-3} / \mathrm{L}\right)\end{array}$ \\
\hline Ref. & $\begin{array}{c}\text { (CAMPOS, 2012; } \\
\text { ESQUIVEL et al., 2012) }\end{array}$ & $\begin{array}{l}\text { CAMPOS, 2012; } \\
\text { ESQUIVEL et al., 2012, } \\
\text { and 2017) }\end{array}$ & $\begin{array}{l}\text { (CAMPOS, 2012; } \\
\text { ESQUIVEL et al., 2012, } \\
\text { and 2017) }\end{array}$ & $\begin{array}{l}\text { (CAMPOS, 2012; } \\
\text { ESQUIVEL et al., 2012, } \\
\text { 2016, and 2017) }\end{array}$ & $x$ \\
\hline RW & 7.8 & 3.42 to 4.2 & 5.4 to 6 & 8.6 to 8.64 & N.A. \\
\hline $\mathrm{FW}(\mathrm{P} 2)$ & 5.5 & 3.32 to 3.6 & 4.3 & 0.02 to 0.22 & N.A. \\
\hline$\%$ average removal & 29 & 11 & 26 & 98 & $\mathbf{x}$ \\
\hline
\end{tabular}

RW- raw water (source-Lagoa do Peri); FW- filtered water (production well); NA- Not analyzed; DoC- Dissolved Organic Carbon; TOC- Total Organic Carbon; DO- Dissolved oxygen.

Source: Adapted by the authors from Sens (2006), Sens and Dalsasso (2007), Mondardo (2009), Campos (2012), Esquivel (2012, 2016, and 2017)

Concerning the chemical aspects related to the degradation dynamics of OM, Esquivel (2012) mentioned that the process begins with the rapid consumption of DO, leading to an increase in nitrate ion (due to ammonium oxidation and the onset of OM degradation), and elevated manganese, iron, and sulfide values as the travel time increases. Even with the low OM reduction observed by the DOC analysis (Table 3), the removal of DOM (through absorbance results at $254 \mathrm{~nm}$ ) responsible for the formation of trihalomethanes (THM) stands out (CAMPOS, 2012).

Campos (2012) and Esquivel et al. (2012, and 2016) highlight that the DO decrease indicates the occurrence of anoxic conditions, which is in agreement with the low oxide-reduction potential obtained in P2 (ORP in RW = 52 in FW = -307) (ESQUUIVEL et al., 2012) according to Table 4. With the low oxygen in the medium, microorganisms continue to use other electron-accepting species such as OM.

Esquivel et al. (2012 and 2017), in a more indepth study, observed that the lake water presented around $8.6 \mathrm{mg} \mathrm{O} / \mathrm{L}$. Through P2 monitoring, redox conditions were identified in the first meters of infiltration, where practically all oxygen, nitrate and sulfate were consumed. Iron and manganese dissolved, and the odor confirmed the presence of hydrogen sulfide. There was a gradual decrease of iron (II) and sulfide ions 
with increasing distance and depth to P2, where pyrite $\left(\mathrm{FeS}_{2}\right)$ formation occurs, as well as possible precipitation of iron carbonate $\left(\mathrm{FeCO}_{3}\right)$. The concentration of manganese ions (II) increased as it approached P2.

Regarding the Trihalomethane Formation Potential (THMFP), Esquivel (ESOUIVEL et al., 2012) perceived a seasonal behavior, with a higher THMFP concentration at higher temperature periods, possibly due to the desorption/ dissolution of natural organic matter (NOM). The decrease in UV-254 nm absorbance values in the systems and the reduction of specific ultraviolet absorption (SUVA), as shown in Table 4 , demonstrated that the water infiltration in the soil, on the well source route, preferentially promotes the THMPF removal in relation to the entire NOM. Esquivel concluded, through a first-order kinetic model, that the removal of NOM and THMFP occurs in the first days of infiltration, and the reduction of easily degradable NOM occurs in less than 2 days. As such, the moderately degradable fraction would need 60 to 90 days of travel to have $95 \%$ removal. An increase in travel time to remove slowly degradable NOM, which in practice is non-degradable, would not significantly change the removal achieved in their studies as about $95 \%$ of THMFPs are present in the easily degradable OM fraction (ESQUIVEL et al., 2012, and 2017).

Table 4 - Evaluation of chemical parameters by Esquivel studies in P2.

\begin{tabular}{|c|c|c|c|c|c|c|c|}
\hline & ORP (mV) & $\begin{array}{c}\text { THMFP( } \mu \mathrm{g} \\
\mathrm{CHCl} / \mathrm{L})\end{array}$ & $\begin{array}{l}\text { \% oxygen } \\
\text { saturation }\end{array}$ & $\mathrm{S}^{2-}(\mathrm{mg} / \mathrm{L})$ & $\mathrm{H}_{2} \mathrm{~S}(\mathrm{mg} / \mathrm{L})$ & $\mathrm{SO}_{4}{ }^{2-}(\mathrm{mg} / \mathrm{L})$ & SUVA $(\mathrm{L} / \mathrm{m} \cdot \mathrm{mg})$ \\
\hline RW & 52 & 73 & 96 to 96.2 & $<0.01$ & 0.007 & 3.06 & 2.3 \\
\hline FW & -307 & 51 & 2 to 2.25 & 0.018 to 0.02 & 0.018 & $<0.52$ & 1.9 \\
\hline
\end{tabular}

RW - raw water (source-Lagoa do Peri); FW- filtered water (production well); ORP - Oxide-reduction potential; THMFP - Trihalomethane Formation Potential; SUVA- specific ultraviolet absorption.

Source: Adapted by the authors from Esquivel et al. (2012, and 2017).

Microbiological parameters were performed only for P1. The first analyses of BF efficiency for the removal of phytoplankton, including cyanobacteria and, more specifically, Cylindrospermopsis raciborski, were performed by Sens et al. (2006), whose results demonstrated $100 \%$ removal (Table 5). In later studies of Sens and Dalsasso (2007), Mondardo (2009), Romero et al. (2014), similar results were obtained. Studies also showed improvement in FW quality in $\mathrm{P} 1$, which refers to the presence of equivalent saxitoxins, and no traces were found after treatment.

In all studies, none of the parameters in Table 5 were detected: they were either absent or undetected. Laboratory research involving sediments from the lake bank indicated that the removal of phytoplankton, cyanobacteria and $C$. raciborski occurs in the first centimeters of the filter medium, reaching values of 94 to $100 \%$ removal. The OM present in the bank sediments, mechanisms of adsorption and degradation, production flow and travel time, were aspects that influenced the biological results (SENS and DALSASSO, 2007). The removal rates of saxitoxins and neosaxitoxins ranged from 40 to $100 \%$ (SENS and DALSASSO, 2007; MONDARDO, 2009; ROMERO et al., 2014; SOARES et al., 2019). 
Table 5 - Results of biological parameters in Peri Lake.

\begin{tabular}{|c|c|c|c|c|}
\hline & Cyanobacteria (cells/mL) & $\begin{array}{l}\text { Cylindrospermopsis } \\
\text { raciborskii (cells/mL) }\end{array}$ & Phytoplankton (cells/mL) & $\begin{array}{l}\text { Dissolved saxitoxin } \\
\text { equivalent ( } \mu \mathrm{g} / \mathrm{L})\end{array}$ \\
\hline Ref. & $\begin{array}{c}\text { (ROMERO et al., 2014; SENS } \\
\text { and DALSASSO, 2007; SENS } \\
\text { et al., 2006) }\end{array}$ & $\begin{array}{l}\text { (MONDARDO, 2009; } \\
\text { ROMERO et al., 2014; SENS } \\
\text { and DALSASSO, 2007; SENS } \\
\text { et al., 2006) }\end{array}$ & $\begin{array}{l}\text { (MONDARDO, 2009; } \\
\text { ROMERO et al., 2014; SENS } \\
\text { and DALSASSO, 2007; SENS } \\
\text { et al., 2006) }\end{array}$ & $\begin{array}{l}\text { (MONDARDO, 2009; } \\
\text { ROMERO et al., 2014; SENS } \\
\text { and DALSASSO, 2007; SENS } \\
\text { et al., 2006) }\end{array}$ \\
\hline RW & $1.3 \cdot 10^{6}$ to $1.53 .10^{6}$ & $9.43 .10^{5}$ to $1.22 .10^{6}$ & $1.4 .10^{6}$ to $1.55 .10^{6}$ & 3.8 to 6.05 \\
\hline FW (P1) & A or ND & A or ND & A or ND & ND \\
\hline
\end{tabular}

RW- raw water (source-Peri Lake); FW- filtered water (production well); A - absent; ND- Not detected.

Source: Adapted by the authors from Sens (2006), and Sens and Dalsasso (2007), Mondardo (2009), Romero et al. (2014)

\subsubsection{Modeling}

The implementation of the bank filtration system in Peri Lake provided conditions for the application of simulations and computational modeling that could generate information about the hy- draulics of the applied process, as well as confirm the observations obtained in the field. New scenarios and conditions could be explored using models 1 (ESQQUIVEL et al., 2012), 2 (SOARES, 2015) and 3 (VARELA et al., 2018), according to Table 6.

Table 6 - Synthesis of the models elaborated from field research.

\begin{tabular}{|c|c|c|c|}
\hline Modeling & Hypotheses & Scenarios & Main Results \\
\hline \multirow{2}{*}{$\begin{array}{l}1 \\
\text { (ESQUUIVEL et al., 2012) }\end{array}$} & \multirow{2}{*}{$\begin{array}{l}\text { Estimate the travel } \\
\text { time of the water to the } \\
\text { production wells and } \\
\text { the natural behavior of } \\
\text { groundwater. }\end{array}$} & 1) No pumping & $\begin{array}{l}\text { From the bottom of the lake to where the well grooves begin at } 20 \mathrm{~m} \\
\text { from the lake and } 9.5 \text { m deep, it was an estimated } 190 \text { days. }\end{array}$ \\
\hline & & 2) With pumping & $\begin{array}{l}\text { With a flow of } 30 \mathrm{~m}^{3} / \mathrm{d} \text { of water, the minimum estimated time was at } \\
\text { least } 80 \text { days. The water in the lake naturally infiltrates towards the } \\
\text { piezometer system. }\end{array}$ \\
\hline \multirow{4}{*}{$\stackrel{2}{(\text { SOARES, 2015) }}$} & \multirow{4}{*}{$\begin{array}{l}\text { Evaluate the behavior of } \\
\text { groundwater in different } \\
\text { BF pumping scenarios, } \\
\text { at flows of } 100 \mathrm{~L} / \mathrm{s} \text { and } \\
200 \mathrm{~L} / \mathrm{s} \text { and considering } \\
\text { different levels of bank } \\
\text { clogging. }\end{array}$} & $\begin{array}{l}\text { 1) Natural water } \\
\text { availability conditions }\end{array}$ & $\begin{array}{l}\text { The lake feeds the aquifer and the Sangradouro channel, which is also } \\
\text { fed by groundwater. }\end{array}$ \\
\hline & & $\begin{array}{l}\text { 2) Decreased water level of } \\
\text { the lake }\end{array}$ & $\begin{array}{l}\text { The more the surface water level decreases, the more the channel is } \\
\text { fed by groundwater, adopting an identity of flow gain and losing the } \\
\text { characteristic of influential water body. With an applied flow rate of } \\
100 \mathrm{~L} / \mathrm{s} \text {, under favorable conditions, the infiltration rates in the lake } \\
\text { remain constant. }\end{array}$ \\
\hline & & 3) In dry conditions & $\begin{array}{l}\text { The flow of groundwater goes to the well gallery, reducing the natural } \\
\text { recharge of the lake caused by the infiltration, and the channel suffers } \\
\text { water loss due to pumping. }\end{array}$ \\
\hline & & The 3 scenarios above & $\begin{array}{l}\text { With an applied flow of } 200 \mathrm{~L} / \mathrm{s} \text {, in all conditions, the infiltration rate } \\
\text { in the lake remains constant and the aquifer suffers a decrease, being } \\
\text { even greater in periods of drought, where the channel does not receive } \\
\text { water from the aquifer and provides flow loss (worst scenario). }\end{array}$ \\
\hline \multirow{3}{*}{$\begin{array}{l}3 \\
\text { (VARELA et al., 2018) }\end{array}$} & \multirow{3}{*}{$\begin{array}{l}\text { Define the best water } \\
\text { catchment scenario on } \\
\text { the banks of Peri Lake. }\end{array}$} & 1) Possible flows & Maximum exploitation supported by the $15 \mathrm{~m}^{3} / \mathrm{h}(4.17 \mathrm{~L} / \mathrm{s}$ per well). \\
\hline & & $\begin{array}{l}\text { 2) Number of possible } \\
\text { wells }\end{array}$ & $\begin{array}{l}\text { Maximum quantity of } 15 \text { wells, totaling a maximum flow of } 62.5 \mathrm{~L} / \mathrm{s} .15 \\
\text { wells operating at } 15 \mathrm{~m}^{3} / \mathrm{h} \text { would not generate saline wedge intrusion. }\end{array}$ \\
\hline & & $\begin{array}{l}\text { 3) Possibility of } \\
\text { approaching the water } \\
\text { treatment station (Casan). }\end{array}$ & $\begin{array}{l}15 \text { wells with a flow of } 15 \mathrm{~m}^{3} / \mathrm{h} \text { allocated closer to the water treatment } \\
\text { station, would generate impairment in } 4 \text { wells due to the saline wedge } \\
\text { coming from the proximity to the sea. }\end{array}$ \\
\hline
\end{tabular}

Source: Adapted by the authors from Esquivel, et al. (2012), Soares (2015) and Varela et al. (2018).

\subsection{Barra da Lagoa - Florianópolis (SC): Study site characterization}

Barra da Lagoa is a neighborhood located in the eastern region of Florianópolis island, as shown in Fig. 3. The location has the UTM coordinates of $753835.29 \mathrm{~m} \mathrm{E}$ and $6948108.09 \mathrm{~m} \mathrm{~S}$, zone 22.
The saline water catchment station is located approximately $50 \mathrm{~m}$ from the sea (BURGARDT, 2017). The soil in Barra da Lagoa corresponds to a sedimentary aquifer composed of elements that vary from coarse to fine sand and may present small amounts of silt and clay (GUEDES JúNIOR, 2005). 
The angular filtration system, where the production well is tilted at an angle between $-20^{\circ}$ and $-45^{\circ}$ with the soil level used by Burgardt (BURGARDT, 2017; BURGARDT et al., 2017; BURGARDT and SENS, 2018), aimed at improving the characteristics of sea water for subsequent referral to the reverse osmosis process.

The angular capture system used by Burgardt (2017) was designed with a length of $70 \mathrm{~m}$ (being $30 \mathrm{~m}$ in the sea), with a pump house and a discharge pipe 4,200 m long. The PVC pipe for suction was $160 \mathrm{~mm}$ in nominal diameter (ND) and $200 \mathrm{~mm}$ in DN, for the discharge pipe. For the water suction, four sets of motor pumps (4 CV) associated in parallel were used, repressing an average of $41.66 \mathrm{~m}^{3} / \mathrm{h}(11.57 \mathrm{~L} / \mathrm{s})$ (BURGARDT, 2017; BURGARDT et al., 2017; BURGARDT and SENS, 2018). A phytoplankton screen at the entrance of the system prevented the capture points from being blocked by fine sediments such as sand and small solids, as protection, besides, the project had a backwash operation when there was a lower quality of filtered water or less flow (BURGARDT, 2017).

Soil samples at $1 \mathrm{~m}, 3 \mathrm{~m}, 4 \mathrm{~m}$ and $6 \mathrm{~m}$ in depth, as well as sand contained on the surface, were analyzed in order to compare the samples sub- mitted to climatic conditions with samples from the subsoil. The local sand presented, on average, from 1 to $6 \mathrm{~m}$ in depth, $0.17 \mathrm{~mm}$ and $0.24 \mathrm{~mm}$ in effective diameter-D10, and D-60, respectively. The surface sand presented $0.23 \mathrm{~mm}$ and $0.28 \mathrm{~mm}$ of effective diameter-D10 and D-60, respectively. The uniformity coefficient was, on average, 1.39. This shows that, over the $6 \mathrm{~m}$ depth, the characteristics of the filter medium undergo little change, being quite uniform as well. These results give the site the ability to remove impurities (BURGARDT, 2017).

\subsubsection{Water quality characterization: physical and chemical parameters}

Physical and chemical parameters were analyzed weekly between August and September 2016 (BURGARDT, 2017; BURGARDT et al., 2017; BURGARDT and SENS, 2018), and the results are shown in Table 7. The authors observed that the levels of salinity and electrical conductivity indicated that water filtration originated from the ocean, without mixing with fresh groundwater. There was also a considerable decrease in turbidity and apparent color. True color, TDS and DOC did not show a significant decrease in FW, nor did the absorbance at $254 \mathrm{~nm}$.

Table 7 - Results of the physical and chemical parameters obtained in Barra da Lagoa.

\begin{tabular}{|c|c|c|c|c|c|c|c|c|c|c|}
\hline & $\begin{array}{c}\text { Apparent } \\
\text { Color } \\
\text { (Pt-Co } \\
\text { Units) }\end{array}$ & $\begin{array}{c}\text { True Color } \\
\text { (Pt-Co } \\
\text { Units) }\end{array}$ & $\begin{array}{c}\text { Turbidity } \\
\text { (NTU) }\end{array}$ & TDS (mg/L) & Temp. $\left({ }^{\circ} \mathrm{C}\right)$ & $\begin{array}{c}\text { Absorbance } \\
254 \mathrm{~nm} \\
\left(\mathrm{~cm}^{-1}\right)\end{array}$ & $\begin{array}{c}\text { DOC } \\
(\mathrm{mg} / \mathrm{L})\end{array}$ & $\begin{array}{c}\text { Electrical } \\
\text { conductivity } \\
(\mu \mathrm{S} / \mathrm{cm})\end{array}$ & pH & $\begin{array}{c}\text { Salinity } \\
(\mathrm{g} / \mathrm{kg})\end{array}$ \\
\hline RW & $\begin{array}{c}30.6 \text { to } \\
32.77\end{array}$ & 3.8 to 3.97 & 2.37 to 2.65 & $\begin{array}{c}34.200 \text { to } \\
34.474\end{array}$ & $\begin{array}{l}19.1 \text { to } \\
20.05\end{array}$ & $\begin{array}{c}0.022 \text { to } \\
0.025\end{array}$ & 4.43 to 5.23 & 48.7 to 50.78 & 8.31 & $\begin{array}{c}34.5 \text { to } \\
35.39\end{array}$ \\
\hline FW (P1) & 5.3 & 3.23 to 3.6 & 0.13 to 0.15 & $\begin{array}{c}33.200 \text { to } \\
34.148\end{array}$ & $\begin{array}{c}19.1 \text { to } \\
19.95\end{array}$ & 0.022 to 0.2 & 3.71 to 4.54 & 48.2 to 5024 & 8.11 & $\begin{array}{c}34.4 \text { to } \\
35.34\end{array}$ \\
\hline $\begin{array}{c}\% \text { average } \\
\text { removal }\end{array}$ & 83 & 5 & 95 & 3 & $\mathbf{x}$ & 12 & 13 & $\mathbf{x}$ & $x$ & $x$ \\
\hline
\end{tabular}

RW- raw water (source-Barra da Lagoa); FW- filtered water (production well); Pt-Co- Color Unit, NTU- Turbidity Unit; TDS-Total Dissolved Solids; DOC-Dissolved Organic Carbon.

Source: Adapted by the authors from Burgardt (2017).

The system also showed a decrease in dissolved organic compounds, but on a smaller scale, con- sidering the results of absorbance $254 \mathrm{~nm}$ and DOC. The parameters of $\mathrm{pH}$, salinity and elec- 
trical conductivity did not change significantly, showing a simple reduction, while the temperature remained constant (BURGARDT, 2017).

\subsection{Aquaculture Lake - Ituporanga (SC): Study site characterization}

Ituporanga is a municipality in the state of Santa Catarina, Brazil, which has the UTM coordinates of $638149.00 \mathrm{~m} \mathrm{E}$ and $6966884.00 \mathrm{~m}$ S zone 22. It is located $163 \mathrm{~km}$ from the city of Florianópolis, the state capital. The BF facilities used by Soares (2009) were located next to an aquaculture lake on the EPAGRI's premises. The purpose of the system was the treatment of lake water for animal drinking.

The location chosen for drilling showed a higher constitution of coarse sand $(32.4 \%)$ in the first $1.2 \mathrm{~m}$ of depth, followed by fine sand $(91 \%)$ in the second layer of soil (1.20 to $2.10 \mathrm{~m}$ ), with low clay and silt content. Subsequent predominance of clay (50\%) was observed in the third layer, following up to $4.6 \mathrm{~m}$. The porosity of the second layer corresponded to about 30 to $35 \%$, with hydraulic conductivity (K) of $5.4 \times 10^{-4} \mathrm{~m} / \mathrm{s}$. It was observed that the lake shore presented an average hydraulic conductivity around $2.22 \times 10^{-7} \mathrm{~m} / \mathrm{s}$, indicating sediment clogging and little potential for infiltration (SOARES, 2009).

A production well was drilled with a depth of 2.8 $\mathrm{m}$ and a diameter of $1 \mathrm{~m}$. The well flow at the ma- ximum (dynamic) level corresponded to $0.03 \mathrm{~L} / \mathrm{s}$, according to the rainfall conditions of the period, with intermittent pumping. It was observed that, in an average obtained from 100 days of operation, $25 \%$ of the water filtered by the well originated from the lake and the rest came from the aquifer. The time taken from the water to the well corresponded to about 70 days (SOARES, 2009).

\subsubsection{Water quality characterization: physical, chemical and biological parameters}

Table 8 shows the physical parameters analyzed in the aquaculture lake between 2009 and 2010. There was an increase in FW of 4 and 5 times of apparent color and turbidity, respectively (SOARES, 2009). A 6-fold increase in turbidity was also observed by Soares (2009) and Romero et al. (2010), who considered the influence of clay and iron in the increase observed in the apparent color and turbidity parameters, with a small true color removal. It was taken into account that such aspects were influenced by rainfall at the site and the leaching capacity of the compounds in the soil as well. The occurrence of iron and manganese in FW could also be correlated with the observed physical results. There was a $100 \%$ removal of TDS and $12 \%$ of SS (suspended solids), whose low removal was attributed to the accommodation of the soil around the well (SOARES, 2009).

Table 8 - Results of physical parameters obtained in the aquaculture lake.

\begin{tabular}{|c|c|c|c|c|c|c|}
\hline & $\begin{array}{c}\text { Apparent color } \\
\text { (Pt-Co Units) }\end{array}$ & $\begin{array}{c}\text { True color } \\
\text { (Pt-Co Units) }\end{array}$ & Turbidity (uNTU) & TDS (mg/L) & SS (mg/L) \\
\hline RW & 136.6 & 55.3 & 16.4 & 10.9 & 98 \\
\hline FW & 512 & 42.5 & 87.2 & 0.05 & 27.5 \\
\hline \% removal & $\mathbf{x}$ & $\mathbf{2 3}$ & $\mathbf{x}$ & $\mathbf{1 0 0}$ & $\mathbf{1 2}$ \\
\hline FW/RW & $\mathbf{4}$ & $\mathbf{x}$ & $\mathbf{5}$ & $\mathbf{x}$ & $\mathbf{x}$ \\
\hline
\end{tabular}

RW- raw water (aquaculture lake); FW- filtered water (production well); FW / RW- parameter increase in FW; NTU - turbidity unit; TDS- total dissolved solids; SS- suspended solids.

Source: Adapted by the authors from Soares (2009). 
Table 9 presents the results of the chemical parameters obtained in the aquaculture lake (SOARES, 2009). The increase of total iron, manganese (II), nitrite and nitrate ions in the FW was observed by Soares (2009). Romero et al. (2010) also observed a 6-fold increase in total iron concentration after BF. These results were related to the clogging of the bottom of the source and long travel time, since the hydraulic permeability at the site proved to be limited (SOARES, 2009).
Moreover, oxygen reduction over the course of the journey and the closing of the banks allowed the solubilization of compounds, such as iron and manganese, found in FW after precipitation. Such aspects also influenced the increase in the alkalinity and electrical conductivity observed, in addition to the chemical characteristics of the soil at the site (SOARES, 2009).

Table 9 - Results of the chemical parameters obtained in the aquaculture lake.

\begin{tabular}{|c|c|c|c|c|c|c|c|c|c|}
\hline & $\begin{array}{c}\text { Total } \\
\text { Alkalinity } \\
\text { (mg } \\
\left.\mathrm{CaCO}_{3} / \mathrm{L}\right)\end{array}$ & $\begin{array}{c}\text { Electrical } \\
\text { conductivity } \\
(\mu S / \mathrm{cm})\end{array}$ & $\begin{array}{c}\text { Total iron } \\
\text { (mg/L) }\end{array}$ & $\mathrm{Mn}^{2+}(\mathrm{mg} / \mathrm{L})$ & $\mathrm{pH}$ & $\begin{array}{c}\text { Absorbance } \\
254 \mathrm{~nm} \\
\left(\mathrm{~cm}^{-1}\right)\end{array}$ & $\mathrm{NO}_{2}^{-}$(mg/L) & $\mathrm{NO}_{3}^{-}(\mathrm{mg} / \mathrm{L})$ & $\mathrm{DO}(\mathrm{mg} / \mathrm{L})$ \\
\hline RW & 19.6 & 21.2 & 0.42 & 0.094 & 7.5 & 0.117 & 0.0065 & 0.13 & 9 \\
\hline FW & 68.4 & 101 & 2.8 & 0.4 & 6.03 & 0.13 & 0.036 & 0.22 & 2.8 \\
\hline \% removal & $\mathbf{x}$ & $\mathbf{x}$ & $x$ & $x$ & $x$ & $x$ & $x$ & $x$ & 69 \\
\hline FW/RW & 3 & 5 & 7 & 4 & $\mathbf{x}$ & 1.1 & 6 & 2 & $\mathbf{x}$ \\
\hline
\end{tabular}

RW- raw water (aquaculture lake); FW- filtered water (production well); FW / RW- parameter increase in FW; DO- dissolved oxygen

Source: Adapted by the authors from Soares (2009).

Table 10 shows that there was a reduction in miRO et al., 2010), identifying the absence of E. Coli crobiological parameters (SOARES, 2009; ROMEand Phytoplankton in the treated water.

Table 10 - Results of biological parameters obtained in the aquaculture lake.

\begin{tabular}{|c|c|c|c|c|c|}
\hline & \multicolumn{2}{|c|}{ Total coliforms (MPN/100 $\mathbf{~ m L )}$} & \multicolumn{2}{c|}{$\begin{array}{c}\text { Total phytoplankton } \\
\text { (cells/mL) }\end{array}$} & E. coli (MPN/100 $\mathbf{~ m L ) ~}$ \\
\hline Ref. & (SOARES, 2009) & (ROMERO et al., 2010) & (SOARES, 2009) & (SOARES, 2009) & (ROMERO et al., 2010) \\
\hline RW & 12000 & 10000 & 8300 & 160 \\
\hline FW & 170 & 1.77 log & A & A & 2.15 log \\
\hline \% removal & $\mathbf{9 8 . 3}$ & $\mathbf{9 7 . 8}$ & $\mathbf{1 0 0}$ & $\mathbf{1 0 0}$ \\
\hline
\end{tabular}

RW- raw water (aquaculture lake); FW- filtered water (production well); MPN - most probable number; A- absent.

Source: Adapted by the authors from Soares (2009) and Romero et al. (2010)

\subsection{Itajaí do Sul River - Ituporanga (SC): Study site characterization}

Ituporanga is a city located in the central-west region of the State of Santa Catarina. It is located $163 \mathrm{~km}$ from the state capital, Florianópolis. The Itajaí do Sul River is the main watercourse in the region, belonging to the Itajaí do Sul sub-basin, which covers 10 municipalities in Santa Catarina, including Ituporanga. The stretch of the Itajaí do Sul River that was part of the study area, belonging to Ituporanga, has the UTM coordinates of $637862.24 \mathrm{~m} \mathrm{E}$ and $6967007.30 \mathrm{~m} \mathrm{~S}$, zone 22, altitude of $370 \mathrm{~m}$, annual rainfall ranging from 1,300 to $1,500 \mathrm{~mm}$ and precipitation daily maximum of $120 \mathrm{~mm}$. The section of the river studied, $33 \mathrm{~m}$ wide on average, was approximately $3 \mathrm{~km}$ downstream of agricultural areas and approximately $23 \mathrm{~m}$ from the urban perimeter. The po- 
sition of surface water in relation to agricultural areas was approximately 3 and $10 \mathrm{~m}$ (vertical and horizontal distance, respectively) (MICHELAN, 2010; ROMERO et al., 2010; MICHELAN et al., 2011; GUEDES et al., 2018).

The subsoil of the perforated site showed a constitution of clay, silt and fine sand in the first 1.2 $\mathrm{m}$ of depth, followed by a layer of silt (58.16\%), fine sand (29.61\%), clay (6.74 \%), medium sand (4\%) and coarse sand (1.49\%) up to 3.9 meters deep, where the predominance of fine, medium and coarse gravel (50.22\%) started. It was considered that the last layer contributed to a hydraulic permeability (K) of $3.0 \times 10-3 \mathrm{~m} / \mathrm{s}$. Michelan (2010) obtained a weighted effective porosity of $19 \%$, with a travel time of 15 days while Romero et al.(2010) found $36.2 \%$ porosity, with a travel time of 28 days.
The production well, located $18.5 \mathrm{~m}$ from the source, was dug in order to measure $4.7 \mathrm{~m}$ in depth and $1 \mathrm{~m}$ in diameter. The well went into operation with a maximum production flow of $12.76 \mathrm{~m}^{3} / \mathrm{d}(0.15$ L/s) (MICHELAN, 2010; ROMERO et al., 2010; MICHELAN et al., 2011; GUEDES et al., 2018).

\subsubsection{Water quality characterization: physical, chemical and biological parameters}

Table 11 shows that there was partial removal of all the studied physical parameters, except in the studies by Romero et al. (2010) where a small increase in TDS of 1.2 times in FW was observed (non-Tabulated result). The turbidity removal was more expressive, on average $68 \%$, with Romero et al. (2010) achieving $84 \%$ removal of this parameter.

Table 11 - Results of the physical parameters obtained in the Itajaí do Sul River.

\begin{tabular}{|c|c|c|c|c|c|}
\hline & $\begin{array}{l}\text { Apparent color } \\
\text { (Pt-Co Units) }\end{array}$ & $\begin{array}{l}\text { True color } \\
\text { (Pt-Co Units) }\end{array}$ & Turbidity (NTU) & TDS (mg/L) & Temp. $\left({ }^{\circ} \mathrm{C}\right)$ \\
\hline Ref. & $\begin{array}{c}\text { (MICHELAN, 2010; } \\
\text { ROMERO et al., 2010) }\end{array}$ & $\begin{array}{c}\text { MICHELAN, 2010; } \\
\text { ROMERO et al., 2010) }\end{array}$ & $\begin{array}{l}\text { (MICHELAN, 2010; } \\
\text { MICHELAN et al., 2011; } \\
\text { ROMERO et al., 2010) }\end{array}$ & $\begin{array}{l}\text { MICHELAN, 2010; } \\
\text { MICHELAN et al., 2011) }\end{array}$ & $\begin{array}{c}\text { (MICHELAN, 2010; } \\
\text { ROMERO et al., 2010) }\end{array}$ \\
\hline RW & 229 to 231 & 40 to 44 & 32 to 36.5 & 43 to 45 & 20.7 to 22 \\
\hline FW & 120 to 181 & 49 to 54 & 6 to 13 & 34 to 44.2 & 19.7 to 21 \\
\hline$\%$ average removal & 35 & 10 & 68 & 12 & $\mathbf{x}$ \\
\hline
\end{tabular}

RW- raw water (Itajaí do Sul River); FW- filtered water (production well); NTU - Turbidity Unit, TDS - Total Dissolved Solids, FW / RW - parameter increase in FW. Source: Adapted by the authors from Michelan (2010), Romero et al. (2010) and Michelan et al. (2011)

Among the chemical parameters analyzed, according to Table 12, the increase in PA of 4 times on average in the total iron concentration stands out (MICHELAN, 2010; ROMERO et al., 2010; MICHELAN et al., 2011; GUEDES i, 2018), a factor associated to Michelan et al. (2010) with a decrease in DO (54\%), which causes the compound to solubilize.
Other parameters that suffered an increase in FW were nitrate ions and, mainly, ammonia, with an 11-fold increase in relation to the source. The degradation of organic compounds was also observed through the absorbance results of $254 \mathrm{~nm}$ and TOC (MICHELAN, 2010). 
Table 12 - Results of the chemical parameters obtained in the Itajaí do Sul River.

\begin{tabular}{|c|c|c|c|c|c|c|c|c|c|c|}
\hline & $\begin{array}{l}\text { Tot. h } \\
\text { (mg C }\end{array}$ & $\begin{array}{l}\operatorname{ardness} \\
\left.\mathrm{aCO}_{3} / \mathrm{L}\right)\end{array}$ & $\begin{array}{l}\text { Tot. iron } \\
\text { (mg/L) }\end{array}$ & pH & $\begin{array}{l}\text { Abs. } 254 \\
\mathrm{~nm}\left(\mathrm{~cm}^{-1}\right)\end{array}$ & TOC (mg/L) & $\begin{array}{c}\mathrm{NO}_{2}^{-} \\
(\mathrm{mg} / \mathrm{L})\end{array}$ & $\mathrm{NO}_{3}^{-}(\mathrm{mg} / \mathrm{L})$ & $\mathrm{NH}_{3}(\mathrm{mg} / \mathrm{L})$ & $\mathrm{DO}(\mathrm{mg} / \mathrm{L})$ \\
\hline Ref. & $\begin{array}{l}\text { ROMERO } \\
\text { et al., } \\
\text { 2010) }\end{array}$ & $\begin{array}{c}\text { (MICHELAN, } \\
\text { 2010) }\end{array}$ & $\begin{array}{l}\text { (GUEDES et } \\
\text { al., 2018; } \\
\text { MICHELAN, } \\
\text { 2010; } \\
\text { MICHELAN } \\
\text { et al., 2011; } \\
\text { ROMERO et } \\
\text { al., 2010) }\end{array}$ & $\begin{array}{l}\text { GUEDES et } \\
\text { al., 2018; } \\
\text { MICHELAN, } \\
2010 ; \\
\text { ROMERO et } \\
\text { al., 2010) }\end{array}$ & $\begin{array}{l}\text { MICHELAN, } \\
\text { 2010; } \\
\text { ROMERO et } \\
\text { al., 2010) }\end{array}$ & $\begin{array}{c}\text { (MICHELAN, } \\
\text { 2010) }\end{array}$ & $\begin{array}{c}\text { (MICHELAN, } \\
\text { 2010) }\end{array}$ & $\begin{array}{c}\text { (MICHELAN, } \\
\text { 2010) }\end{array}$ & $\begin{array}{l}\text { (MICHELAN, } \\
\text { 2010) }\end{array}$ & $\begin{array}{l}\text { (GUEDES et } \\
\text { al., 2018; } \\
\text { MICHELAN, } \\
\text { 2010) }\end{array}$ \\
\hline RW & 19.4 & 20.6 & 0.42 to 1.26 & 6.4 to 6.7 & 0.22 to 0.32 & 4.4 & 0.06 & 0.38 & 0.6 & 8.7 \\
\hline FW & 12.9 & 26.4 & 2.82 to 4.9 & 5.8 to 6.1 & $\begin{array}{c}0.078 \text { to } \\
0.079\end{array}$ & 3.7 & $<0.1$ & $<0.1$ to 0.589 & 6.8 & 4 \\
\hline $\begin{array}{c}\% \text { average } \\
\text { removal }\end{array}$ & 33.5 & $x$ & $\mathbf{x}$ & $\mathbf{x}$ & 71 & 16 & 83 & $x$ & $\mathbf{x}$ & 54 \\
\hline FW/RW & $\mathbf{x}$ & 1.32 & 4 & $\mathbf{x}$ & $x$ & $x$ & $x$ & 1.6 & 11 & $\mathbf{x}$ \\
\hline
\end{tabular}

RW- raw water (source-Itajaí do Sul River); FW- filtered water (production well); TOC- Total organic carbon, DO- dissolved oxygen.

Source: Adapted by the authors from Michelan (2010), Romero et al. (2010), Michelan et al. (2011), Guedes et al. (2018)

Regarding microbiological parameters, Table 13 shows the efficiency of BF in the removal of total coliforms (MICHELAN, 2010; ROMERO et al., 2010) and E. coli (MICHELAN, 2010; ROMERO et al., 2010; MICHELAN et al., 2011). In another study, Michelan et al. (2011) mention the removal of 2 logs of total coliforms.

Table 13 - Results of the biological parameters obtained in the Itajaí do Sul River.

\begin{tabular}{|c|c|c|}
\hline & Total coliforms (MPN/100 mL) & E. coli (MNP/100 mL) \\
\hline Ref. & (MICHELAN, 2010; ROMERO et al., 2010 & $\begin{array}{l}\text { MICHELAN, 2010; MICHELAN et al., 2011; } \\
\text { ROMERO et al., 2010) }\end{array}$ \\
\hline RW & 20000 to 25000 & 1500 to 3300 \\
\hline FW & 140 to 170 & 3.8 to 5.2 \\
\hline$\%$ average removal & 99.3 & 99.8 \\
\hline
\end{tabular}

RW- raw water (source-Itajaí do Sul River); FW- filtered water (production well); MNP- most probable number.

Source: Adapted by the authors from Michelan (2010), Romero et al. (2010), Michelan et al. (2011)

\subsection{Carbofuran removal}

The BF removal of the pesticide Carbofuran, frequently observed in the Itajaí do Sul River, was verified. The results show that, on average, it is possible to remove around $69 \%$ of the pesticide in FW (MICHELAN, 2010; ROMERO et al., 2010).

For more details regarding carbofuran removal using BF technology, Michelan (2010) carried out a test involving filtration columns whose results showed a travel time of 25 days for the removal of carbofuran in the order of $80 \%$. The half-life of the compound in the system corresponded to 10.5 days at neutral $\mathrm{pH}$.

\subsection{Belo River - Orleans (SC): Study site characterization}

Orleans is a municipality located in southern Santa Catarina, as shown in Fig. 3, and is $196 \mathrm{~km}$ away from the state capital, Florianópolis. The BF system approached by Guedes (GUEDES, 2018; GUEDES et al., 2019) corresponded to the structure located on the Belo River bank, about 2.16 $\mathrm{km}$ from the source, inserted in the rural area of Orleans, Santa Catarina, which has the UTM coordinates of $667449.00 \mathrm{~m} \mathrm{E}$ and $6831854.00 \mathrm{~m}$ S zone 22. In addition to the abstraction well, the system was composed of pumping that was performed using photovoltaic energy. 
The granulometric composition of the banks of Belo River found coarse sand (34.5\%), medium sand $(22.4 \%)$, fine gravel $(21.6 \%)$, fine sand (19.7\%) and medium gravel (1.4\%), in addition to clay and silt ( $0.89 \%)$. The composition of the site showed a flow condition for sediment transport, and the effective soil porosity varied from $29 \%$ to $32.5 \%$ (GUEDES, 2018; GUEDES et al., 2019).

The geological profile of the land presented clay and silt (up to $2 \mathrm{~m}$ deep), basalt rocks and sand (between 2 to $5 \mathrm{~m}$ ) in addition to coarse sand ( 5 to $10 \mathrm{~m}$ deep), considering the water level of the corresponding groundwater at an average depth of $2.5 \mathrm{~m}$. The hydraulic conductivity of the soil presented an average of $5.2 \times 10^{-5} \mathrm{~m} / \mathrm{s}$, typical for sediments composed of coarse and medium sand (GUEDES, 2018; GUEDES et al., 2019).

The production well, called P1, was built 8 inches in diameter, $15 \mathrm{~m}$ deep and was located $17 \mathrm{~m}$ from the source. The time taken from the water to the well fluctuated between 16 and 32 days, depending on the lowering of the aquifer and the pump used, the pumping being intermittent (GUEDES, 2018). Subsequently, Guedes et al. (2019), in a second production well (P2) $1 \mathrm{~m}$ in diameter and $5 \mathrm{~m}$ deep, $25 \mathrm{~m}$ from the source, also pumped intermittently, as the energy supply system was through photovoltaic cells. It was also possible to identify the hydraulic connection between the water in the wells and the source (GUEDES, 2018; GUEDES et al., 2019).

\subsubsection{Water quality characterization: physical, chemical and biological parameters}

The results in Tables 14, 15 and 16 represent the physical, chemical and biological parameters, respectively, obtained in the production wells $\mathrm{P} 1$ (GUEDES, 2018) and P2 (GUEDES et al., 2019). Table 14 shows the excellent efficiency of $B F$ in removing the studied physical parameters, both in $\mathrm{P} 1$ and in P2, with removal percentages above $95 \%$.

Table 14 - Results of physical parameters obtained in Belo River.

\begin{tabular}{|c|c|c|c|}
\hline & Apparent color (Pt-Co Units) & True color (Pt-Co Units) \\
\hline RW & 94.5 & 22.7 & Turbidity (NTU) \\
\hline FW (P1) & 4.9 & 0.4 & 0.3 \\
\hline \% average removal & 95 & 98 & NA \\
\hline RW & 146.1 & NA & 18.4 \\
\hline FW (P2) & 0.8 & NA & 0.3 \\
\hline \% average removal & 99 & 98 & \\
\hline
\end{tabular}

RW- raw water (source-Belo River-Orleans); FW- filtered water (production well); NTU - turbidity unit.

Source: Adapted by the authors from Guedes (2018); Guedes et al. (2019)

In Table 15, it is possible to observe that there was an increase of 1.3 and 1.2 in the electrical conductivity (GUEDES, 2018; GUEDES et al., 2019) due to the chemical characteristics of the sediments, influencing the composition of the leachate materials, such as the release of soil ions. The BF efficiency in the total iron removal was also observed in both wells. There was a DOC reduction, showing the degradation of organic compounds during filtration (GUEDES, 2018) of $\mathrm{DO}$, as well as a decrease in $\mathrm{pH}$, which was much greater in $\mathrm{P} 2$. 
Table 15 - Results of chemical parameters obtained in Belo River.

\begin{tabular}{|c|c|c|c|c|c|}
\hline & $\begin{array}{l}\text { Electrical conductivity } \\
\qquad(\mu \mathrm{S} / \mathrm{cm})\end{array}$ & Total iron $(\mathrm{mg} / \mathrm{L})$ & pH & $\mathrm{DOC}(\mathrm{mg} / \mathrm{L})$ & $\mathrm{DO}(\mathrm{mg} / \mathrm{L})$ \\
\hline RW & 72.3 & 0.9 & 6.8 & 2.8 & 7.8 \\
\hline FW (P1) & 95.7 & 0.1 & 6.3 & 0.9 & 5.1 \\
\hline$\%$ average removal & $\mathbf{x}$ & 89 & $x$ & 68 & 35 \\
\hline FW/RW & 1.3 & $x$ & $x$ & $x$ & $x$ \\
\hline RW & 66.1 & 1.2 & 6.4 & NA & 7.5 \\
\hline FW (P2) & 81.2 & 0.1 & 5.2 & NA & 5.4 \\
\hline$\%$ average removal & $x$ & 92 & $\mathbf{x}$ & $\mathbf{x}$ & 28 \\
\hline FW/RW & 1.2 & $x$ & $x$ & $x$ & $x$ \\
\hline
\end{tabular}

RW- raw water (source-Belo River-Orleans); FW- filtered water (production well); FW/RW - increment of the parameter in the FW; DOC - Dissolved organic carbon; DO - dissolved oxygen.

Source: Adapted by the authors from Guedes (2018); Guedes et al. (2019)

The system's location in a rural area justifies the presence of microbiological contaminants due to the existence of animal husbandry in the region, in addition to the possibility of illegal effluent discharges along the source path. In the data in Table 16, the absence of E. Coli after BF is observed in both wells without, however, eliminating total coliforms (GUEDES, 2018; GUEDES et al., 2019). Nonetheless, $99.99 \%$ of removal was obtained.

Table 16 - Synthesis of the biological parameters of the research in Belo River.

\begin{tabular}{|c|c|c|c|c|c|}
\hline & $\begin{array}{c}\text { Total coliforms } \\
\text { (MPN/100ml) }\end{array}$ & E. coli (MPN/100ml) & & $\begin{array}{c}\text { Total coliforms } \\
\text { (MPN/100 mL) }\end{array}$ & E. coli (MPN/100ml) \\
\hline RW & 110000 & 6800 & RW & 84000 & 4900 \\
\hline FW (P1) & 15.3 & A & FW (P2) & 4,5 & A \\
\hline \% average removal & 99.99 & 100 & \% average removal & 100.0 & 100 \\
\hline
\end{tabular}

RW- raw water (source-Belo River-Orleans); FW- filtered water (production well); MPN - most probable number.

Source: Adapted by the authors from Guedes (2018); Guedes et al. (2019)

\section{FINAL CONSIDERATIONS}

From the content prepared for Part 1 of this review, for the correct application of BF, sustainable sources from surface and underground water must be relied on in hydraulic connection with the local aquifer formed by alluvial or unconsolidated materials. The hydrogeology of the aquifer, the hydrology of the water body, the morphology of the river or lake, the composition of its bottom and its quality in addition to the temperature of the surface and groundwater are other local characteristics to consider when applying BF (ESQQUIVEL et al., 2016).

As discussed in Burgardt (2017), the BF technique does not remove salinity. In these cases, BF can be at least used as pre-treatment of water desalination plants for supply systems. Regarding carbofuran, Michelan (2010) conducted a test involving filtration columns with results that showed a travel time of 25 days for a removal in the order of $80 \%$.

In all studies carried out, the flow rates applied were low to the point of representing something consistent for the real scale of a public supply system. In the future, it would be interesting to accomplish a study that analyzed quality and quantity (higher flows) to understand what will happen with the travel time and its final quality.

As can be seen in this review, among the parameters involved in the studies presented, the BF 
technique demonstrates efficiency in reducing parameters such as: turbidity and coliforms (total and fecal), pesticides and toxins. However the technique showed low capacity to reduce parameters, for example: salinity and true color. Parameters such as $\mathrm{pH}$ and dissolved oxygen do not change significantly.

It is also important to note that once the technique is dependent on the soil composition inherent to local geological conditions, parameters as iron, manganese, fluorine, alkalinity, hardness and chlorides can be added to the treated water as a function of the redox conditions during runoff as well as through variation flow, changing the contribution of the source and aquifer.

In summary, for public supply systems, BF can be used to make pre-treatment in already consolidated situations, that is, in systems in operation (water treatment plants), which can make the raw water quality reach the beginning of treatment with the same standards of water quality (or better standards, for example: less turbidity) as when the current treatment systems were conceived (start of operation), causing them to have a longer useful life or even a greater flow. The final considerations will be presented in the second part of this review.

\section{AUTHORS' CONTRIBUTION}

All authors worked equally in the preparation of this scientific article.

\section{REFERENCES}

BURGARDT, T. Filtração em sedimento do mar como prétratamento a osmose reversa. Dissertation (Master in Environmental Engineering), Universidade Federal de Santa Catarina. p. 130, Florianópolis-SC, 2017.

BURGARDT, T., PIZZOLATTI, B. S., BORGES, L. K., and SENS, M. L. Filtração angular em sedimento de praia como pré-tratamento a osmose inversa. In: Saneamento Ambiental: Desenvolvimento e Qualidade de Vida na Retomada do Crescimento - Congresso ABES/FENASAN. 2017. São Paulo. Anais...

BURGARDT, T. and SENS, M.L. Filtração em margem de mar como pré tratamento para a dessalinização da água. Revista Eletrônica do PRODEMA, 2018. 12 (1): p. 30-37. https://doi.org/1022411/ rede2018.1201.03

CAMPOS, L. P. S. Filtração em margem no tratamento de água: avaliação da aplicação da técnica no manancial da Lagoa do Peri, Santa Catarina, e análise prévia de viabilidade de aplicação em Rio Grande, Rio Grande do Sul. Completion of course work, Sanitary and Environmental Engineering, Universidade Federal de Santa Catarina- UFSC. p. 60, Florianópolis-Santa Catarina, 2012.

DONALD, D.; GRYGASKI, T. Development of a Sustainable Potable Water Supply for Rural Villages in The Coastal Region of Tanzania, Africa. Ontario: WW Engineering, 2002. 36 p.

ESQQUIVEL, L. G. R., GRISCHEK, T., PIZZOLATTI, B. S., MONDARDO, R. I. , and SENS, M. L. Bank filtration in a coastal lake in South Brazil: water quality, natural organic matter (NOM) and redox conditions study. Clean Technologies and Environmental Policy, 2017. 19 (8): p. 2007-2020.

ESQUIVEL, L. G. R., PIZZOLATTI, B. S., and SENS, M. L. Potencial de aplicação da filtração em margem em Santa Catarina, Brasil. Interciência, 2016. 41, 740-747. Disponível em: http://www. redalyc.org/articulo.oa?id=33948191003. Acessado em: 02 Oct. 2019. https://doi.org/10.1007/s10098-017-1382-5

ESQUUIVEL, L. G. R., PIZZOLATTI, B. S., and SENS, M. L. Tratamiento de agua potable por filtración inducida en una laguna costera en el sur de Brasil. Tecnología en Marcha, 2012. 25 (4): p. 23-32. https://doi.org/10.18845/tm.v25i4.616

GUEDES JÚNIOR, A. Áreas de proteção ambiental para poços de abastecimento público em aqüíferos costeiros. Thesis (Doctorate in Production Engineering), Universidade Federal de Santa Catarina (UFSC). p. 184, Florianópolis-SC, 2005.

GUEDES, T. L. Avaliação do desempenho de um sistema de filtração em margem de rio com bombeamento fotovoltaico. Thesis (Doctorate in Environmental Engineering), Universidade Federal de Santa Catarina. p. 207, Florianópolis-SC, 2018.

GUEDES, T. L., MICHELAN, D. C. G. S., LEAL, L. L., PAIVA, A. L. R., BURGARDT, T., CABRAL, J. J. S. P., DALSASSO, R. L., and SENS, M. L. Occurrence of iron in bank filtration wells: case studies in Ituporanga (SC) and Garanhuns (PE). Desalination and Water Treatment, 2018. 101: p. 170-177. https://doi.org/10.5004/ dwt.2018.21764

GUEDES, T. L., SOUZA, F. H., GHISI, D. B., PEREZ, A. B. A., DALSASSO, R. L., and SENS, M. L. Aplicação da filtração em margem de rio como alternativa de tratamento de água para comunidades isoladas. Revista DAE, 2019. 67: p. 84-94. https://doi.org/ 10.4322/dae.2019.007 
HISCOCK, K. M. and GRISCHEK, T. Attenuation of groundwater pollution by bank filtration. Journal of Hydrology, 2002. 266: $\mathrm{p}$. 139-144. https://doi.org/10.1016/S0022-1694(02)00158-0

MICHELAN, D. C. G. S. Filtração em margem de rio precedendo a filtração lenta, para remoção de carbofurano, em tratamento de água para consumo humano. Thesis (Doctorate in Environmental Engineering) Universidade Federal de Santa Catarina. p. 342, Florianópolis-SC, 2010.

MICHELAN, D. C. G. S., PIZZOLATTI, B. S., SOARES, M. B., DALSASSO, R. L., and SENS, M. L. Desempenho do sistema filtração em margem seguida de filtração lenta retrolavável em Ituporanga Santa Catarina. Revista DAE, 2011. 59: p. 28-36. https://doi. org/10.4322/dae.2014.078

MONDARDO, R. I. Avaliação da filtração em margem como pré-tratamento à filtração direta descendente na remoção de células de cianobactérias e saxitoxinas. Thesis (Doctorate in Environmental Engineering), Universidade Federal de Santa Catarina- UFSC. p. 291, Florianópolis- Santa Catarina, 2009.

OLIVEIRA, J. S. Analise sedimentar em zonas costeiras: subsidio ao diagnostico ambiental da Lagoa do Peri - Ilha de Santa Catarina, Brasil. Dissertation (Master in Geography), Universidade Federal de Santa Catarina-UFSC. p. 169, Florianópolis-SC, 2002.

RABELO, L. Estudos preliminares para implantação da filtração em margem na Lagoa do Peri como pré-tratamento de água para remoção de fitoplâncton. Dissertation (Master in Environmental Engineering), Universidade Federal de Santa Catarina- UFSC. p. 152, Florianópolis-Santa Catarina, 2006.

RAY, C., MELIN, G., and LINSKY, R. B. Riverbank Filtration improving source-water quality. Vol. 43. 2003, California, USA: Kluwer Academic.

ROMERO, L. G., MONDARDO, R. I., SENS, M. L., and GRISCHEK, T. Removal of cyanobacteria and cyanotoxins during lake bank filtration at Lagoa do Peri, Brazil. Clean Technologies and Environmental Policy, 2014. 16 (6): p. 1133-1143. https://doi. org/10.1007/s10098-014-0715-x

ROMERO, L. G., PIZZOLATTI, B. S., SOARES, M. B. D., MICHELAN, D. C. G. S., and SENS, M. L. Bank filtration: Application in rural areas. Case studies in Santa Catarina, Brazil. In: 21st Century Watershed Technology: Improving Water Quality and Environment Conference Proceedings, 21-24 February 2010, Universidad EARTH, Costa Rica. 2010. St. Joseph, MI: ASABE. Anais...
SANTOS, G. F., SILVA, J. T. N., MENDONÇA, M., and VEADO, R. W. Análise ambiental da Lagoa do Peri. Geosul, 1989. 4 (8): p. 101123.

SENS, M. L. and DALSASSO, R. L. Bank filtration of reservoir as an efficient technique for water supply treatment. In: Reservoir and River Basin Management: Exchange of Experiences from Brazil, Portugal and Germany. GUNKEL, G.S., M.C. Technical University of Berlin: Alemanha. 253. 2007.

SENS, M. L., MONDARDO, R. I., DALSSASSO, R. L., and MELO FILHO, L. C. Filtração em Margem. In: Contribuição ao estudo da remoção de cianobactérias e microcontaminantes orgânicos por meio de técnicas de tratamento de água para consumo humano. 2006, PROSAB-04: Minas Gerais. p. 173-236.

SILVA, R. L. Aspectos limnológicos, variabilidade espacial e temporal na estrutura da comunidade fitoplanctônica da Lagoa do Peri. Santa Catarina, Brasil. Thesis (Doctorate), Universidade Federal de São Carlos-UFSCar. p. 218, 1999.

SIMONASSI, J. C. Caracterização da Lagoa do Peri, através da análise de parâmetros físicoquímicos e biológicos, como subsídio ao gerenciamento dos recursos hídricos da llha de Santa Catarina, SC, Brasil. Dissertation (Master in Production Engineering), Universidade Federal de Santa Catarina-UFSC. p. Florianópolis-SC, 2001.

SOARES, M. The Influence of High Infiltration Rates, Suspended Sediment Concentration and Sediment Grain Size on River and Lake Bed Clogging. Thesis (Doctorate), Technischen Universität Berlin. p. 143, 2015.

SOARES, M. B. D. Estudo da Implantação em escala real da Filtração em Margem em Lago de piscicultura extensiva para dessedentação animal. Dissertation (Master in Environmental Engineering), Universidade Federal de Santa Catarina. p. 130, Florianópolis-SC, 2009.

SOARES, M., PIZZOLATTI, B. S., and SENS, M. L. Estudo Hidrogeológico Preliminar para a Avaliação do Potencial de Colmatação do Sedimento das Margens da Lagoa do Peri e do Canal Sangradouro - Florianópolis - Santa Catarina - para a Implantação da Técnica da Filtração em Margem. In: Anuário do Instituto de Geociências - UFRJ, 2019: p. 46-55. https://doi. org/10.11137/2019_4_46_55

VARELA, S. C., GUIGUER JÚNIOR, N., ZANATTA, L., and PREIS, C. M. Modelagem numérica para a avaliação da disponibilidade hídrica e da intrusão de cunha salina para a captação de águas subterrâneas na Lagoa do Peri. In: XX Congresso Brasileiro de Águas Subterrâneas. 2018. Campinas-SP. 